\title{
On the need for a new narrative of business
}

\author{
Hunter Lovins* \\ Professor Bard College, President Natural Capitalism Solutions, Member of the Executive Committee, Longmont, \\ CO, USA
}

\begin{abstract}
Unsustainable business practices endanger our own survival. Current business, rooted in the toxic neo-liberal narrative is endangering life as we know it. This piece, invited by the Open Working Group of the United Nations to help it frame the new Sustainable Development Goals (SDGs), sketches the pillars of a regenerative narrative for business that can lead towards an economy in service to life.
\end{abstract}

Keywords: regenerative capitalism, narrative, Sustainable Business, sustainability

\section{The problems}

The global economy rests on a knife-edge. It is based on unsustainable business practices that are driving societies and ecosystems into successive collapses. There are many palliative "fixes" that can prop the system up—but only for a time.

What is needed is a new development paradigm, one based on recognizing that the economy depends wholly on preserving a healthy ecosystem. The current paradigm is, based on what Randy Hayes calls Cheater Capitalism, ${ }^{1}$ in which incumbent technologies are subsidized, corporate profits are socialized and the too-big-to-fail are bailed out, but individuals are told to make their own way in a dog-eat-dog "free" market. Yet we believe the shared story that in capitalism the smartest win, everyone has equal opportunity to get rich, techno-genius' like Bill Gates have the money, so will save the world. The unspoken option is to stand with out hands out. ${ }^{2}$

We need a new strategy of change.

\footnotetext{
${ }^{1}$ Randy Hayes, "Rethinking Society From the Ground Up," www. asap4all.org, in articles

${ }^{2}$ Peter Buffett, "the Charitable Industrial Complex," New York Times, 26 July 2013, http://www.nytimes.com/2013/07/27/ opinion/the-charitable-industrial-complex.html

*Corresponding author: Hunter Lovins, Professor Bard College, President Natural Capitalism Solutions, Member of the Executive Committee, Club of Rome, 11823N. 75th Street, Longmont, CO 80503, USA. Tel.: +1 720684 6580; E-mail: hlovins@ naturalcapitalism.org.
}

Many are suggesting that the challenge facing the world is a question of story. Thomas Berry put it: "We are in trouble just now because we do not have a good story ... . The Old Story-the account of how the world came to be and how we fit into it.... sustained us for a long period of time. It shaped our emotional attitudes, provided us with a life purpose, energized action. It consecrated suffering, integrated knowledge, guided education.... We need a story that will educate man, heal him, guide him"3

The marketing expert A.J. Grant agreed, saying, "You walk into the future by laying the runway out in front of you. You clear the impediments littering the ground, smooth the surface, and enable people to see the route. If you want to change a paradigm, Grant says, you have to tell a better story"4

Change WILL happen because humanity is facing extreme challenges. The world IS changing all around us. Ecosystems are collapsing. In 2010, Global Biodiversity $3,{ }^{5}$ building on the 2005 Millennium Ecosystem Assessment, ${ }^{6}$ warned that climate change and other assaults are tipping three of the earth's major ecosystems into collapse: by the end of this century, business as usual, there will be no living coral reefs on planet earth. The Amazon now releases more carbon than it

\footnotetext{
${ }^{3}$ http://www.journeyoftheuniverse.org/storage/The_New_Story.pdf

${ }^{4}$ A.J. Grant, Environmental Communication Associates, http: //teameca.com/

${ }^{5}$ http://www.cbd.int/gbo3/

${ }^{6}$ http://www.maweb.org/
} 
soaks up. The acidifying oceans risk ending life as we know it. ${ }^{7}$ The Planetary Boundaries report from the Stockholm Resilience Center set scientifically agreed safe boundaries for human impacts, and showed how humankind has already exceeded four of these, and is approaching several others. ${ }^{8}$

As the UN sets new goals, it has the chance to tell a very different story, not only about how to meet the challenges facing the globe, but about its own relevance in delivering solutions. It has the opportunity to announce the future before it happens - to tell the story in a new and compelling way. In the present polarized debate everyone brings their U-haul truck of facts to justify their point of view - but fact don't drive change. It has always been thus in a human species that is yet little removed from cave men sitting round a fire telling stories. As Johan Sachs in his vital book Winning the Story Wars: Why Those Who Tell And Live The Best Story Will Rule The Future demonstrates, the compelling story wins. Take for example the photo of pink slime, whose viral spread put a whole industry out of business in matter of weeks. Occupy Wall Street rose from unknown to a brand recognized by $70 \%$ of people in the world in four months time. Both were more compelling stories.

The financial crash of 2008 was a taste of what is coming, and a collapse-prone world is a bad platform for development policy.

The collapse caused $\$ 50$ trillion dollars and 80 million jobs to evaporate. ${ }^{9}$ And the wreck's not over. The grim statistics include: ${ }^{10}$

* 69 of 118 countries with available data show an increase in the percentage of people reporting worsening living standards in 2010 compared to 2006.

* People in half of 99 countries surveyed say they have little confidence in their national governments.

* In 2010 , more than $50 \%$ of people in developed countries lack decent jobs (in the youth segment in Greece, Italy, Portugal, Slovenia, and Spain, it's more like $50 \%$.

\footnotetext{
${ }^{7}$ Third Global Biodiversity Outlook, http://www.cbd.int/doc/ publications/gbo/gbo3-final-en.pdf

${ }^{8}$ Johan Rockstrom et al., "A Safe Operating Space for Humanity," Nature, 23 Sept 2007, http://www.nature.com/news/ specials/planetaryboundaries/index.html

${ }^{9}$ Pia Lee-Brago, "ILO: Recession, massive job loss threaten global economy," The Philippine Star, 2 Nov 2011, http://www.philstar. com/Article.aspx ?articleId=743718\&publicationSubCategoryId=

${ }^{10}$ International Labor Organization World of Work Report 2011, http://www.twnside.org.sg/title2/resurgence/2011/254/econ2.htm
}

* The share of profit in GDP increased in $83 \%$ of countries studied between 2000 and 2009 , but productive investment stagnated globally during the same period.

* Growth in corporate profits increased dividend payouts (from $29 \%$ of profits in 2000 to $36 \%$ in 2009) and financial investment (from 81.2\% of GDP in 1995 to $132.2 \%$ in 2007). The crisis slowed the trend, but it resumed in 2010. Bankers regained their bonuses, but workers face falling wages.

* Food price volatility doubled during the 2006-2010 relative to the preceding five years. Financial investors benefit from this; food producers do not.

Nobel Laureate Economist Joseph Stiglitz observed, "Unless we have a better understanding of the causes of the crisis, we can't implement an effective recovery strategy. And, so far, we have neither." His diagnosis: ideological driven release of the financial sector from the regulations that had prevented collapse since the 1930s, bubble-fueled consumption and growing inequality. His prescription: strong government expenditures, aimed at facilitating restructuring, promoting energy conservation, and reducing inequality, and a reform of the global financial system to create productive investment instead of buildup of reserves. ${ }^{11}$ It is critical, as John Fullerton of the Capital Institute ${ }^{12}$ points out, that we shift flows of finance into the productive assets that will transform the economy to what he calls Regenerative Capitalism. These investments include renewable energy, ${ }^{13}$ sustainable agriculture, ${ }^{14}$ radically sustainable manufacturing, ${ }^{15}$ and creating resilient communities. ${ }^{16}$

Despite warnings that the economy faces continuing peril, ${ }^{17}$ governments are doing none of this. Fixated on austerity (read, ensuring profits of bankers, rather than investing in real prosperity in communities), they threaten the quality of life not only in the PIIGS

\footnotetext{
${ }^{11}$ Stiglitz, Joseph, "To Cure the Economy," 3 Dec 2011, http://www. project-syndicate.org/commentary/stiglitz143/English

${ }^{12} \mathrm{http}$ ///www.capitalinstitute.org/

${ }^{13}$ See e.g. West Coast Clean Economy, Center for Climate Strategies, 2013, http://www.climatestrategies.us/library/library/view/972

${ }^{14}$ See, e.g. http://www.savoryinstitute.com/

${ }^{15} \mathrm{http}$ //www.natcapsolutions.org/UNIDO/UNIDO_TheFutureofInd ustryinAsia_NCS.pdf

${ }^{16}$ See Transition Towns: http://www.transitionnetwork.org/

${ }^{17}$ Roubini, Nouriel, "Is Capitalism Doomed," Aljezzera, 18, Aug 2011, http://english.aljazeera.net/indepth/opinion/2011/08/2011 816104945411574.html
} 
economies, but across the globe. ${ }^{18}$ Developing nations struggle to lift from poverty the half the world's population that lives on less than $\$ 2.50$ a day. Millions of drought-driven refugees in the north of Africa, join people threatened by too much or too little glacial melt water and monsoon floods from the Himalaya to Columbia. ${ }^{19}$ It is clear that climate change will hit the most vulnerable hardest. ${ }^{20}$ Yet, these poorest three billion emit only seven percent of emissions. The richest seven percent [about half a billion people] spew out 50 percent. $^{21}$

The global dependence on fossil fuels that drives the climate crisis, in turn, endangers the economy. Unregulated manipulation of derivatives and unwise mortgage practices clearly contributed. But the run-up in commodities prices in the spring of 2008 that forced homeowners to choose between paying for gasoline to drive to work or paying their mortgages clearly played a role, as well. Six months before the financial collapse, oil prices hit $\$ 150$ a barrel, and when gasoline in the inefficient US exceeded $\$ 5$ a gallon (far below prices in Europe) the housing market collapsed. ${ }^{22}$

Such price spikes did not inflict uniform damage. Between 2005 and 2010 Exxon, Chevron, Shell and BP reduced their US workforce by 11,200 workers $^{23}$ but pocketed $\$ 4$ billion a year in tax subsidies. Globally subsidies to the fossil fuel industry top $\$ 550$ billion every year, ${ }^{24}$ at least 12 times any subsidies given

\footnotetext{
${ }^{18}$ CJ Polychroniou, “Austerity's Failure in Greece: Time to Think the Unthinkable?,“ Truthout 7 August 2013, http://www.truthout.org/news/item/18027-austeritys-failure-in-greece-time-to-thinkthe-unthinkable

${ }^{19}$ Spotts, Peter N., "Little Time to Avoid Big Thaw, Scientists Warn," Christian Science Monitor, 24 March 2006, http://www.csmonitor.com/2006/0324/p01s03-sten.html

${ }^{20}$ Oxfam America, Africa Action, OneWorld US, OneClimate.net, Environmental Defense, Greenpeace International, World Wildlife Fund, "Climate Disasters Threaten to 'Overwhelm Aid Systems," 22 April 2009, http://us.oneworld.net/article/361990-climate-disastersthreaten-overwhelm-aid-systems. And http://www.alternet.org/food/ 151578/millions_of_african_climate_refugees_desperate_for_food, water

${ }^{21}$ Angus, Ian, and Butler, Simon, Too Many People, Haymarket Books, 2011.

22 "Location, Location, Location Efficiency: Can Smart Growth Help Beat the Mortgage Crisis?" 27 January 2010, http://www.nrdc.org/media/2010/100127.asp

${ }^{23} \mathrm{http}$ ://thinkprogress.org/green/2012/01/31/415242/exxonmobilmade-411-billion-in-2011-but-pays-estimated-176-percent-tax-rate/

24 “"Energy Subsidies: Getting the Prices Right," International Energy Agency, 2010, http://www.iea.org/files/energy_subsidies.pdf. The International Energy Agency has called for the end of these payments if the world wishes to avoid irreversible climate change.http://www.guardian.co.uk/environment/2011/nov/09/fossil-
}

to energy efficiency and renewable energy. ${ }^{25}$ In 2011 Exxon made $\$ 5$ million in profit every hour, or over $\$ 41$ billion, but paid lower taxes than the average American. In 2012, as oil prices hit $\$ 120$ a barrel, oil companies made an additional $\$ 5$ billion from American workers. And of course, the impact is far worse on people in developing nations, so governments there subsidize fuel prices to avoid revolution, consumers treat the cheaper good as plentiful and the dance goes on. The recent collapse in oil prices pleases consumers, but threatens oil dependent nations. Big oil companies that have lost $\$ 200$ billion since June 2014, are laying off even more workers. $^{26}$

Issues of inequality are not only immoral, but threaten economic stability. Dr's Richard Wilkinson and Kate Pickett have shown that health and social problems are worse in more unequal countries. ${ }^{27}$ Their book, The Spirit Level, ${ }^{28}$ shows that people in more equal societies live longer, have better mental health and better chances for a good education regardless of background. Community life is stronger where the income gap is narrower, children do better at school and are less likely to become teenage parents. When inequality is reduced, people trust each other more, there is less violence and rates of imprisonment are lower.

Rounding the circle, climate instability and the shift of food to fuel worsened inequality, driving record high food prices and hunger. ${ }^{29}$ To some extent, the primary crisis the globe faces is created by the over-consumption in the North, and both fairness and math dictates that the richer countries lead in transforming their investments to a regenerative economy. But the rapid conventional development in the Global South cannot be sustained, either. Billion dollar investors such as Jeremy Grantham are warning that a major restructuring of global financial flows will be necessary to deal with a world of soaring commodities costs, waning natural capital and all of the challenges described above. ${ }^{30}$ Lester Brown's

\footnotetext{
fuel-infrastructure-climate-change?newsfeed=true

${ }^{25}$ Morales, Alex, "Fossil Fuel Subsidies Are 12 Times Support for Renewables, Study Shows," Bloomberg, 29 July 2010, http://www.bloomberg.com/news/2010-07-29/fossil-fuel-subsidiesare-12-times-support-for-renewables-study-shows.html

${ }^{26}$ http://money.cnn.com/2015/01/07/investing/big-oil-priceenergy-stocks/.

${ }^{27} \mathrm{http}$ ://www.equalitytrust.org.uk/

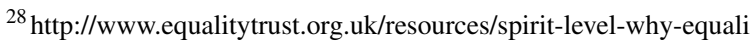
ty-better-everyone

${ }^{29} \mathrm{http} / / /$ richardheinberg.com/bookshelf/peak-everything

${ }^{30} \mathrm{http}$ ://www.bloomberg.com/video/investment-strategist-jeremygrantham-rBP3CUZJS9mPRsuWLXpSRA.html
} 
Full Planet, Empty Plates: The New Geopolitics of Food Scarcity warns, for example, that "grain stocks have dropped to a dangerously low level, while the World Food Price Index has doubled in a decade.... We are only one poor harvest away from chaos in the world grain markets." ${ }^{31}$ Remember, it was a food riot that touched off the Arab Spring in Tunisia. And, as Lester Brown points out, the real concern is not only peak oil, but peak water. ${ }^{32}$ Or in Richard Heinberg's term, "Peak Everything."

These "drivers of change" 33 mean that business as usual is actually the radical scenario for the future. They also mean that the Post 2015 Development Goals must be based on a shared commitment to sustainability. Failure to do this will doom any development regime. Books such as Dimitry Orlov's book, Five Stages of Collapse ${ }^{34}$ and such websites as the Collapse of Industrial Civilization, ${ }^{35}$ or the Dark Mountain ${ }^{36}$ are only three of the growing number of collapse merchants arguing that it is already too late.

Unless countered, this narrative will become a selffulfilling prophecy. Many young people already believe that there is no future for them. Teen suicide is increasing, ${ }^{37}$ as are fears of climate change and other environmental harm. ${ }^{38}$ Teilhard de Chardin said that the future belongs to those who give hope to the next generation. ${ }^{39}$ This, more than anything else, must be our charge.

\footnotetext{
${ }^{31}$ http://www.earth-policy.org/books/fpep

${ }^{32}$ Lester Brown, The Guardian, 6 July 2013, 'The real threat to our future is peak water' http://www.guardian.co.uk/ global-development/2013/jul/06/water-supplies-shrinking-threat-tofood, see also Full Planet, Empty Plates: The New Geopolitics of Food Scarcity (WW Norton 2012).

${ }^{33}$ This is a term Royal Dutch Shell uses when it does scenario planning. If you can identify Drivers of Change you know things are going to change. You can establish strategies to deal with the predictable consequences.

${ }^{34} \mathrm{http} / / /$ cluborlov.blogspot.com/p/the-five-stages-of-collapse.html

${ }^{35} \mathrm{http}: / /$ collapseofindustrialcivilization.com/

${ }^{36}$ Paul Kingsnorth, "Why I stopped believing in environmentalism and started the Dark Mountain Project," 29 Ap 2010, http://www. theguardian.com/environment/2010/apr/29/environmentalism-darkmountain-project

${ }^{37} \mathrm{http}: / /$ www.nydailynews.com/life-style/health/1-12-teensattempted-suicide-report-article-1.1092622

${ }^{38} \mathrm{http} / /$ www.theglobeandmail.com/life/health-and-fitness/health/ youth-anxiety-on-the-rise-amid-changing-climate/article18372258/

${ }^{39} \mathrm{http}: / / w w w . g o o d r e a d s . c o m / q u o t e s / 481614-$ the-future-belongsto-those-who-give-the-next-generation
}

\section{Solutions ${ }^{40}$}

Overlooked by the proponents of collapse is the strong and increasing business case for sustainability. This means that arguing over which should go first, the North or the South is insane. Harvard Business Review put it this way: "Sustainability isn't the burden on bottom lines that many executives believe it to be. It can lower your costs and increase your revenues. That's why sustainability should be a touchstone for all innovation ... .In the future, only companies [and, I would add, countries] that make sustainability a goal will achieve competitive advantage. ${ }^{41}$ That means rethinking business models as well as products, technologies and processes."

More than 55 studies from the likes of the wild-eyed environmentalists at Goldman Sachs agree, showing that the companies who are the leaders in environmental, social and good governance policies have $25 \%$ higher stock value, the fastest growing stock value, deliver superior financial performance and are better investment risks. ${ }^{42}$ In an age of gridlocked Congress, inability of international leaders to frame a successor treaty to Kyoto and the loss of trust in governments following the 2008 collapse, the ensuing Euro-zone crisis and the "jobless recovery" corporate leaders are realizing that the business sector may be the only institution on the planet big enough, well enough managed and resourceful enough to tackle the challenges facing the planet. This is good, but insufficient.

Avoiding collapse will require a combination of international leadership, good policy at the national level, action by states and provinces, a suite of market-based measures, and a growing commitment by corporations and individuals to create the future we want. Most of all, it will require understanding that the economy is, in Herman Daly's phrase, a wholly owned subsidiary of the environment not the other way around.

International leadership is represented by Costa Rica's commitment to become carbon neutral, and China's fledgling effort to implement the circular economy. Introduced in the 1970 s by Walter Stahel, ${ }^{43}$ the

\footnotetext{
${ }^{40}$ For many more solutions see the Solutions Journal, http: //www.thesolutionsjournal.com/ and Natural Capitalism Solutions, www.natcapsolutions.org

${ }^{41}$ Ram Nidumolu, C.K. Prahalad, M.R. Rangaswami, Why Sustainability is Now the Key Driver of Innovation, Harvard Business Review, September 2009, Reprint R0909E.

${ }^{42}$ http://www.natcapsolutions.org/businesscasereports.pdf

${ }^{43}$ Product Life Institute, http://www.product-life.org/
} 
concept became the basis of Chinese development policy in the 11 Party Congress. ${ }^{44}$ If made a foundational element in the post 2015 Development Goals, it would drive economic prosperity. A 2013 report describes how it would net the European manufacturing sector $\$ 630$ billion by $2025 .{ }^{45}$

Nations and the UN must revise the metrics that they use to determine if their policies are succeeding. The release in March 2012 of the 40 years update to Limits to Growth, ${ }^{46}$ and Demos's report, Beyond GDP ${ }^{47}$ challenge the myth that growth is necessary for prosperity, and outline the sort of metrics that must underpin the post 2015 development goals. ${ }^{48}$

Bhutan had been leading world attempts to measure national accounts with the metric of Gross National Happiness. Recent elections cloud this momentum, but the concept is gaining wider application, regardless. Asking what we want more of rather counting only the flow of money and stuff through the economy-Gross National Product-was the basis of the French Commission on the Measurement of Economic Performance and Social Progress, ${ }^{49}$ the Chinese Green GDP, ${ }^{50}$ the UK's Happy Planet Index, ${ }^{51}$ and the Genuine Progress Indicator. $^{52}$

National policies like Germany's Feed-in-Tariff(FiT) have unleashed that country's renewable energy indus-

\footnotetext{
44"Chinese leaders join lawmakers, political advisors in panel discussions," 8 March, 2012, http://newyork.chinaconsulate.org/eng/xw/t912428.htm, http://www.chinadaily.com.cn/ china/2007-01/18/content_786230.htm

${ }^{45}$ Towards a Circular Economy, http://www.ellenmacarthurfoundation.org/about/circular-economy/towards-the-circular-economy

${ }^{46}$ Perspectives on Limits to Growth: Challenges to Building a Sustainable Planet http://si.edu/Content/consortia/limits-to-growth.pdf

${ }^{47}$ Beyond GDP, http://www.demos.org/publication/beyond-gdpnew-measures-new-economy

${ }^{48} \mathrm{http}$ ://www.beyond-gdp.eu/

${ }^{49}$ http://www.stiglitz-sen-fitoussi.fr/documents/rapport_anglais.pdf

${ }^{50}$ Atkisson, Alan, Life Beyond Growth, http://alanatkisson. wordpress.com/2012/02/29/life-beyond-growth/

${ }^{51} \mathrm{http}: / / \mathrm{www}$. neweconomics.org/

${ }^{52}$ All of this work stems from Herman Daly's work in the 1970's on the Index of Sustainable Economic Welfare. In 1995, Clifford Cobb, Ted Halstead and Jonathan Rowe proposed a the Genuine Progress Indicator, taking Daly and Cobb's work further to factor in the value of volunteer work, cost of crime and family breakdown, the cost of underemployment, ozone depletion and the loss of old growth forests. They calculated the GPI from 1950 comparing it to the GDP., to find that we're not even breaking even. This same finding by the Chinese green GDP project resulted in its being consigned to an academic exercise, but it now appears to be re-emerging.
}

try, created jobs and underpinned prosperity. ${ }^{53}$ In their first four years FiTs created almost 500,000 new jobs and cut the unit cost of solar panels enough that they will reach grid parity (costing the same as grid electricity) by $2013 .{ }^{54}$ The program added only two to three Euros per month to electricity bills in Germany, roughly $\$ 50$ to customers' electricity bills each year, for a total of $€ 8.6$ billion. Deutsche Bank found that far from costing the economy, the savings outstripped the total cost of payments made by households. Had customers bought electricity from conventional coal generation, Germans would have paid an additional $€ 9.4$ billion. ${ }^{55}$ BillClinton pointed out that if the US implemented a similar program it would create 2.5 million jobs. ${ }^{56}$ Jobs have become the currency of politics, world-wide, but the typical prescription of growth at any cost turns out not to be the best way to create durable, well-paying jobs. The economy of the future is the green economy. ${ }^{57}$ Renewable energy and energy efficiency deliver 10 times the jobs created per dollar invested as fossil fuel or nuclear plants. ${ }^{58}$

This green economy, now projected to be a $\$ 10$ trillion industry by $2020,{ }^{59}$ is emerging best, however, at the local level, as people realize that they must build their own resilience in the face of an unaccountable global economy. ${ }^{60}$ The failure of global leadership to agree to climate protection at Copenhagen, Cancun and Durban has spurred cities to implement sustainable practices. Denmark's Samso Island is $100 \%$ renewably

\footnotetext{
${ }^{53}$ Osha Gray Davidson, Clean Break, http://www.amazon. co.uk/Clean-Break-Kindle-Single-ebook/dp/B00A4IEJ5K/ref=sr_1_ 3 ? $=$ digital-text $\&$ ie $=U T F 8 \& q i d=1353251900 \& s r=1-3$

${ }^{54}$ Roney, J Matthew, "Solar Cell Production Climbs to Another Record in 2009, Earth Policy Institute," 24 September 2010, http:// www.renewableenergyworld.com/rea/news/article/2010/09/solar-ce 1l-production-climbs-to-another-record-in-2009

55 "Paying for Renewable Energy: TLC at the Right Price Achieving Scale through Efficient Policy Design," Deutsche Bank, December 2009, http://www.dbcca.com/dbcca/EN/investmentresearch/investment_research_2144.jsp

${ }^{56} \mathrm{http}: / /$ www.thedailyshow.com/watch/tue-november-8-2011/billclinton-pt-2

${ }^{57}$ Hunter Lovins, Boyd Cohen, The Way Out: Kickstarting Capitalism To Save Our Economic Ass, Hill \& Wang 2012.

${ }^{58}$ Daniel Kammen, et al., "Putting Renewables to Work: How Many Jobs Can The Clean Energy Industry Generate?" 2004, http://rael. berkeley.edu/sites/default/files/old-site-files/2004/Kammen-Renewa ble-Jobs-2004.pdf

${ }^{59} \mathrm{http}: / / w w w . a m a z o n . c o m / C r e a t i n g-C l i m a t e-W e a l t h-U n l o c k i n g-$ Economy/dp/0989353109

${ }^{60}$ http://www.transitionnetwork.org/
} 
powered. ${ }^{61}$ The German town Wildpoldsried is as well, producing $321 \%$ more energy than it uses and selling the excess for $\$ 5.7$ million each year. ${ }^{62}$ Over half of Germany's renewables are owned not by utilities but by farmers and citizens. ${ }^{63}$ San Francisco is on track to be $100 \%$ renewable by 2020 , Scotland by 2020 , Germany by 2050 , while shuttering its nuclear industry. In 2013 the IEA reckoned that renewable energy would generate more power than natural gas by 2020. In 2015 The 2015 National Bank of Abu Dhabi found that solar energy is on track to achieve grid parity in $80 \%$ of countries within the next 2 years. ${ }^{64}$ This is good news, as already half of the world's people live in cities, three quarters by 2050 . Projections warn that in the next decade or so China will seek to move into cities yet unbuilt more people than there are in the United States. ${ }^{65}$ Just the copper wire this would require is more than current world copper production. ${ }^{66}$ Business as usual, by 2030 China will want more oil than the world now lifts. ${ }^{67}$

Action at the local level will be critical to implementing the Post 2015 Goals. Community-based strategies to protect intact ecosystems and resilient human communities are now proving to be more economically attractive to the majority of people than the current systems that serve to concentrate wealth at the top. For example, coastal communities in South East Asia, which will be disproportionately impacted by rising sea levels driven by climate change caused by emissions from the global north would be far better served by investing in restoring mangroves and sustainable aquaculture than in asset-based tourism economies.

\footnotetext{
${ }^{61}$ Burund, Martin, Living a Green Dream on Danish Island, http: //www.planetark.org/dailynewsstory.cfm/newsid/49847/story.htm

${ }^{62}$ German Village Achieves Energy Independence...And then Some, Biocycle, Aug 2011, http://www.jgpress.com/archives/ free/002409.html

${ }^{63} \mathrm{http}: / /$ www.wind-works.org/coopwind/CitizenPowerConference tobeheldinHistoricChamber.html

${ }^{64} \mathrm{http}: / /$ www.nbad.com/content/dam/NBAD/documents/Business/ FOE_Full_Report.pdf

${ }^{65}$ Ian Johnson, China's Great Uprooting: Moving 250 Million Into Cities, New York Times, 15 June 2013 http://www.nytimes.com/ 2013/06/16/world/asia/chinas-great-uprooting-moving-250-millioninto-cities.html?nl=todaysheadlines\&emc=edit_th_20130616\&_r=0

${ }^{66}$ Peter Hilderson, Jones Lang LaSalle, Asia Pacific, Energy and Sustainability Services Global Sustainability Perspective, Feb 2012.

${ }^{67}$ Brown, Lester, Chuina Forcing World To Rethink Its Economic Future, Earth Policy Institute 5 Jan 2006 http://www.earthpolicy. org/Books/PB2/index.htm
}

Tools like Natural Capitalism's LASER (Local Action for Sustainable Economic Development $)^{68}$ have helped communities from Kazakhstan, to South Africa, to New Zealand to Newburg, New York, implement renewable energy and a whole array of measures to build stronger, locally based economies. Programs like CDP's Cities initiative ${ }^{69}$ are helping major cities to implement climate protection in ways that drive their economies, create jobs and cut costs.

From Seattle to now thousands of towns the world around citizens are developing locally appropriate sustainability indicators to enable them to judge whether they are gaining or losing, and adjust policies to deliver greater well-being. ${ }^{70}$ These metrics enable towns and cities to know that their sustainability investments are enhancing quality of life, helping to meet citizenframed goals and building resilient local economies.

Economists like Robert Reich, former U.S. Secretary of Labor, in such books as Beyond Outrage ${ }^{71}$ and Aftershock, brilliantly analyze the drivers of collapse, and set forth sensible prescriptions for local organizing, reaching across ideologies to build the coalitions that can use federal policies to level inequalities. There are many across the political spectrum alarmed at the challenges facing us, but the demise of common channels of information dissemination has spawned an Internet empowered world of ideological bubbles where people only talk to those of similar perspectives.

A tireless advocate for economic policies that advance the common good, Reich proposes returning tax rates to where they were under such Republican administrations as Eisenhower, and Reagan, restoring the ability of government to provide education, and social services to those now slipping into poverty trying to pay for them in a privatized economy. He calls, also for a return to the banking regulations that kept economic stability for the 80 years since the Great Depression, and whose removal allowed the excesses that triggered the Great Recession. He prescribes forcing banks to restructure underwater mortgages, but perhaps most importantly calls for getting big money out of politics, and in the U.S. overturning Citizens United case that categorizes corporations as persons with First Amendment rights of speech (read: spending money on politicians). He describes the ideological

\footnotetext{
${ }^{68}$ www.global-LASER.org

${ }^{69} \mathrm{https}$ ://www.cdproject.net/CDPResults/CDP-Cities-2013-Global -Report.pdf

${ }^{70} \mathrm{http}: / /$ www.sustainablemeasures.com/

${ }^{71}$ http://robertreich.org/post/21277269422
} 
conflict as between social Darwinism and the public good.

Though Reich's logic is impeccable, in the face of a deadlocked Congress in the U.S. and ossified legislatures abroad, it is unlikely that his wisdom will be heeded. What then? Perhaps the greatest responsibility falls to the corporate sector. Smart industries are beginning to interact with local stakeholders to develop locally appropriate initiatives. For example in agriculture, approaches like Allan Savory's Holistic Management ${ }^{72}$ takes carbon from the air and returns it to the soil while increasing grazing output. Organic farming, which FAO now admits will do a better job of feeding the world's people, is coming to be recognized as a far better alternative than industrial agriculture. ${ }^{73}$ Companies like Mondelez International are linking their work with happiness initiatives, committing to supply $100 \%$ of their coffee sustainably. ${ }^{74}$

At the same time, retail companies are implementing more sustainable practices.

When Walmart asked its global supply chain of 60-90,000 companies to measure their carbon footprints and report them to the Carbon Disclosure Project, ${ }^{75}$ it did more to drive sustainability into even very small companies than years of government regulations. Companies like Puma, Novo Nordisk, Baxter Health care and many others are beginning to count the costs and risks of unsustainability in their financial reporting. They are behaving in ways that are more responsible, and that are enhancing every aspect of core business value. Perhaps most impressive is Unilever's commitment not to report its financials quarterly to Wall St analysts, chiding them that trying to manage a company on a 90 day rotation precludes the sort of longterm value creation that grows shareholder value. They have committed to implement the Unilever Sustainable Living Plan: cutting their environmental impact in half while doubling revenues, sourcing all feedstocks from sustainable agriculture and improving the lives of a billion people.

\footnotetext{
${ }^{72}$ http://www.youtube.com/watch?v=lOpoRdpvlh0

${ }^{73}$ Scialabba, Nadia El-Hage, "Organic Agriculture and Food Security," 2007, Food and Agriculture Organization of the United Nations www.fao.org/organicag, ftp://ftp.fao.org/paia/organicag/ofs/OFS2007-5.pdf

${ }^{74}$ http://www.mondelezinternational.com/deliciousworld/sustainability/coffeemadehappy.aspx

${ }^{75}$ Wal-Mart Announces Partnership with Carbon Disclosure Project to Measure Energy Used to Create Products, 24 Sept 2007, http://walmartstores.com/pressroom/news/6739.aspx
}

This Natural Capitalist ${ }^{76}$ approach is taking hold in companies in three ways that should form the arc of transition in implementing the Post 2015 Goals. First companies are eliminating waste and implementing more efficient use of resources. This drives profitability and buys time, helping to solve the climate crisis, resource constraints and many other challenges. ${ }^{77}$ Second, they are redesigning how we make and deliver everything, using such sustainable approaches as biomimicry, ${ }^{78}$ Cradle to Cradle design, ${ }^{79}$ and the circular economy. ${ }^{80}$ This principle is also profitably being implemented by leading companies. ${ }^{81}$ The third principle, that we manage all institutions to be regenerative of human and natural capital (the forms of capital that underpin all life and this every economy, even if currently uncounted) is being embedded in innovative business schools, and becoming the management philosophy of a whole new generation of business people. $^{82}$

But it is important to recognize that we cannot consume our way out of our problems. Patagonia, long a leader in more sustainable practices, has been growing at $25-30 \%$ a year-in a recession. Their uncompromising commitment to minimizing their footprint and to radical transparency in the impacts that they have is now the inspiration for the Apparel Coalition's Higgs Index, ${ }^{83}$ helping companies implement sustainability throughout their supply chain. ${ }^{84}$ Their legendary founder Yvon Chouinard prides himself on doing the right thing, even-especially-when it seems unreasonable. The first company to commit to $100 \%$ organic cotton, well before the supply was sufficient or the price right, famously ran a full page ad in the NY Times telling shoppers, "Don't buy this jacket!" urging customers to buy fewer things that last longer. In an interview with Greenbiz founder Joel Makower, Yvon said, "If all these companies are doing all these

\footnotetext{
${ }^{76}$ www.natcapsolutions.org

${ }^{77}$ http://www.wbcsd.org/home.aspx

${ }^{78}$ http://biomimicryinstitute.org/

${ }^{79}$ This is Walter Stahel's concept, http://www.product-life.org/, and term, tho borrowed lately by Bill McDonough

${ }^{80} \mathrm{http} / / / \mathrm{www}$. fastcoexist.com/1679241/a-blueprint-for-a-circulareconomy-reusing-and-refurbishing-for-prosperity, http://www.the circulareconomy.org/exec-summary

${ }^{81} \mathrm{http}: / / \mathrm{www}$. interfaceglobal.com/

${ }^{82}$ www.bgi.edu, http://www.aashe.org/resources/sustainability-bus inessmanagement-programs, http://www.educationrevolution.org/

${ }^{83}$ http://www.apparelcoalition.org/higgindex/

${ }^{84} \mathrm{http}: / /$ www.patagonia.com/us/patagonia.go $?$ assetid $=67372$
} 
great sustainability things, why is the world still going to hell? It's the obsession with growth! Companies that have been in business for 500-1000 years focus on three priorities: quality, innovation, and controlled growth ... . There's no difference between a pessimist who says 'We're doomed, why bother?' and an optimist who says 'We're fine, why bother?' Nothing gets done.... If you want to change government, change business, because business runs government. If you want to change business, change consumers. Make consumption uncool!"85

The world has reached, in the words of Naomi Klein, "A no kidding moment." 86 Arab Spring, and the global phenomenon of Occupy are challenging dictatorial regimes and the dominant economic paradigm, delegitimizing the old order. ${ }^{87}$ The new economic model of Regenerative Capitalism, ${ }^{88}$ such movements as Co-op Capitalism ${ }^{89}$ the sharing economy all stress values, community, networks, and collaboration over competition and acquisition. From occupiers who are helping foreclosed homeowners reclaim their houses, ${ }^{90}$ to Spain's Indignados, ${ }^{91}$ to farmers in Japan challenging the nuclear industry, ${ }^{92}$ to the villagers in Wukan voting out corrupt officials, ${ }^{93}$ the global conversation has entered a new phase. People are realizing that the powerful interests that ruled the last century will not solve their problems. They are retaking control over their own lives.

For the global populist movement to make a difference it will have to do more than protest. It will have to install new governments, as well as craft policies to relieve debt and encourage productive investment. Globally, we need to enable Greece and Spain, as well as the developing world, and bankrupt communities

\footnotetext{
$\overline{{ }^{85} \text { http://www.greenbiz.com/video/2013/03/01/patagonia-responsib }}$ le-company

${ }^{86}$ Occupy Everywhere, Democracy Now, 25 Nov 2011, http://www. democracynow.org/2011/11/25/occupy_everywhere_michael_moore_ naomi_klein

${ }^{87}$ Stiglitz, Joseph, The Global 99\%, http://www.slate.com/ articles/business/project_syndicate/2011/11/occupy_wall_street_and_ the_global_trend_against_inequality_.html

${ }^{88}$ http://www.capitalinstitute.org/

${ }^{89} \mathrm{http}: / / \mathrm{www} \cdot \mathrm{uk} \cdot \mathrm{coop} /$ coopcapitalism

${ }^{90} \mathrm{http}: / /$ www.occupy.com/article/why-richmond\%E2\%80\%99splan-rescue-homeowners-could-reshape-mortgage-lending-industry

${ }^{91}$ http://www.thenation.com/article/161229/spains-indignadostake-square

${ }^{92} \mathrm{http}$ //uncannyterrain.com/blog/

${ }^{93}$ http://www.aljazeera.com/programmes/specialseries/2015/02/wukanvotes-150225163032470.html
}

around the world to escape the crushing debt that stifles effort to build prosperity. For example, it would have been far better to pay people at risk of defaulting on their mortgages to enable them to pay the banks and stay in their homes, than to bail out the banks, then allow them to hoard the resulting cash. The banks would get their liquidity, but people would keep their homes and get a fresh start. This is essentially the policy implemented in early August in Richmond California when the city government served notice on the major banks holding mortgages on underwater properties in the jurisdiction to restructure the loans to restore positive value to the properties, and an affordable mortgage to the owners or face eminent domain seizure of the properties by the city, which would then restructure the loans. ${ }^{94}$

The Development Goals need to recognize that there is a difference between debt-fueled consumption and debt for investment in the productive assets of the future. Economic policies that reinforce inequality, and constrain the transition to a green economy impede implementation of more sustainable practices. ${ }^{95}$ Fullerton's white paper "Regenerative Capitalism"96 points out that merely optimizing single variables such as financial return will no longer be sufficient to investment decision-making in the Era of Regenerative Capitalism.

Fullerton states that finance's most important practical function in the real economy is the transformation of savings into investment, and the credit-creation process. The flow of real investment is the bridge to, and the steering mechanism for, the Great Transition. The same planetary boundaries that dictate limits to growth also imply limits to investment, a constraint no economic system in the history of civilization has ever before had to contemplate. How much and where large economic actors invest will have critical implications for collective global security and, consequently, must become a central concern of global governance.

He identifies eight elements of Regenerative Capitalism:

1. Right Relationship: Holding the continuation of life sacred and recognizing that the human economy is embedded in human culture and the biosphere.

2. Innovative adaptive and responsive: Drawing on the innate ability of human beings to innovate and "create anew" across all sectors of society.

\footnotetext{
${ }^{94}$ http://www.truth-out.org/opinion/item/17918-eminent-domainto-save-homeowners

${ }^{95} \mathrm{http}$ ///www.neweconomics.org/projects/new-economic-model

${ }^{96} \mathrm{http}: / /$ capitalinstitute.org/regenerative-capitalism/
} 
3. Wealth Viewed Holistically: True wealth is defined in terms of the well-being of the "whole," achieved through the harmonization of the multiple forms of capital.

4. Empowered Participation: Financial wealth is equitably (although not necessarily equally) distributed in the context of an expanded view of true wealth.

5. Robust Circulatory Flow: A continual striving to minimize energy, material, and resource throughput at all phases of the production cycle, reusing, remanufacturing and recycling materials.

6. "Edge Effect" Abundance: Creative collaborations increase the possibility of value-adding wealth creation through relationship, exchanges, and resiliency.

7. Seeks Balance: Long run ability to learn and grow stronger from shocks, developing adaptability to change that is valued over brittle concentrations of power and hyper-efficiency in the present.

8. Honors Community and Place: Operating to nurture healthy, stable communities and regions, both real and virtual, in a connected mosaic of placecentered economies.

Regenerative Capitalism is already manifesting in scalable real world projects, and enterprises on the ground. ${ }^{97}$ Making it relevant to large global enterprises is a critical challenge. But even here, there is evidence of its presence striving to take root.

Fullerton points out, however, that the ability of Regenerative Capitalism to emerge, particularly within the present mainstream economy dominated by largescale enterprises and State actors, will depend upon a fundamental transformation of finance. He posits Eight Elements of Regenerative Finance, consistent with the shift from a mechanistic to ecological worldview:

1. Means not Ends: finance is a means to a healthy economy, not the "ends" of economic activity.

2. Ethical and In Service: Finance returns to being an ethical profession, grounded in a culture of service to clients and service to the emergence of a regenerative economy.

3. The Supremacy of Relationship: Values relationships over transactions.

4. Transparency: Values transparency over complexity, while embracing genuine value-adding innovation.

\footnotetext{
${ }^{97} \mathrm{http}: / /$ fieldguide.capitalinstitute.org/
}

5. Real Wealth: Seeks to generate long-term wealth creation, harmonizing multiple forms of capital in right relationship, using a fair financial return as a constraint for investment decisions.

6. Right Scale: Appropriately scaled as a system embedded in the economy, which in turn is embedded in culture and the biosphere.

7. Collaborative: Values collaboration among values-aligned investors, financial institutions, and enterprises from multiple sectors, mimicking nature's "edge effect."

8. Resilient: Balances efficiency with structural resiliency at the system level through decentralization, diversity, and buffers within institutions and even within the money system itself.

The economic incentives throughout the present system were structured for a time in history-the first industrial revolution - in which nature was abundant and people scarce. Now, with 10,000 more people arriving on earth every hour and every major ecosystem in decline, we still tax what we want: income and employment, and subsidize what we do not: pollution and depletion of resources. We need full cost accounting, and honest economics.

And we need it fast. In 2012, the OECD, the IEA, the World Bank and the IMF all warned that unless world leaders implement climate protection by 2017 (the World Bank said 2020) infrastructure development will lock-in a world of 6 degree Celsius warming. The changes necessary to confront climate change (and the other daunting problems of our current unsustainable business model) will not be achieved easily. There will be winners and very real losers. Such incumbent industries as fossil fuels, nuclear power generation, toxic manufacturing and others that have received most of the historic subsidies and are driving the collapse of natural systems are collapsing and will be replaced. In April 2015 Bloomberg announced that, "Fossil Fuel Just Lost The Race with Renewables." 98 The cost of the transition will not be trivial. Estimates of the value of what would become stranded fossil assets, now called "the carbon bubble," if the world successfully implements climate protection run as high as $\$ 30$ trillion. ${ }^{99}$ In contrast, the stranded assets in the sub-prime mortgage crisis only amounted to $\$ 2.7$ trillion. Unless carefully managed, implementing a new development paradigm will entail wrenching economic dislocations. The only alternative,

\footnotetext{
${ }^{98}$ http://www.bloomberg.com/news/articles/2015-04-14/fossilfuels-just-lost-the-race-against-renewables

${ }^{99}$ https://capitalinstitute.org/blog/big-choice-0/
} 
however, as Lord Stern pointed out in his report to the UK government, will be devastating environmental and economic dislocations of failing to make the transition to a green economy, costing up to $20 \%$ of global GDP per year. ${ }^{100}$

Here's the math that shows the magnitude of the problem: the world can burn 565 more gigatons of carbon fuel before it becomes impossible to hold the global temperature to 2 degrees $\mathrm{C}$ warming. But as Bill McKibben's global 350.org movement ${ }^{101}$ points out, the fossil fuel companies own and are holding on their books 2,795 gigatons of carbon reserves. Their business model is to dig it up and burn it. If they do, the world roasts. And all of us with it.

It will take, however, a monumental partnership of lawmakers, government officials and citizens to stop them. McKibben is calling for investors to divest in ownership of fossil fuel companies, reminiscent of the South Africa divestment campaign. Since he issued the call early in 201328 universities, 42 cities, 75 religious institutions and 32 foundations have committed to sell their fossil corporate holdings. ${ }^{102}$ Interestingly, even here there is a business case: two investment analysis firms, Impax Asset Management and MSCI, have found that fossil free portfolios are outperforming investments that contain fossil polluters. ${ }^{103}$ A 2013 survey found that more than half of fund managers surveyed had sold or avoided making investments because of concerns over climate change. ${ }^{104}$ FTSE's North American fossil fuel-free index has consistently outperformed the conventional benchmark index. ${ }^{105}$ In an analysis earlier this month, stock market index company MSCI found that fossil-free funds have earned

\footnotetext{
${ }^{100}$ The Stern Review, http://webarchive.nationalarchives.gov.uk/+ /http:/www.hm-treasury.gov.uk/sternreview_index.htm

${ }^{101} \mathrm{http}: / /$ math.350.org/

${ }^{102} \mathrm{http}$ //gofossilfree.org/commitments/

${ }^{103}$ HTTP://GOFOSSILFREE.ORG/ANALYSTS-FOSSIL-FUELFREE-PORTFOLIOS-OUTPERFORM-INVESTMENTS-THATINCLUDE-CARBON-POLLUTERS/

${ }^{104}$ http://www.businessgreen.com/bg/news/2286934/survey-fundmanagers-increasingly-wary-of-climate-change-threat?wt.mc_ev= click\&WT.tsrc $=$ Email\&utm_term $=\& u$ utm_content $=$ Survey $\% 3 \mathrm{~A} \% 20$ Fund $\% 20$ managers $\% 20$ increasingly $\% 20$ wary $\% 20$ of $\% 20$ climate $\%$ 20change $\% 20$ threat\&utm_campaign=BusinessGreen $\% 20$ Weekly $\%$ 20News\%20070813\&utm_source=Business\%20Green\%20Weekly \&utm_medium=Email

${ }^{105} \mathrm{http}$ ///switchboard.nrdc.org/blogs/plehner/divestment_outperforms convent.html
}

a higher return than conventional ones in the last five years. 106

It is important, however, to recognize what markets are good at and for, and what government is better at. Market mechanisms are extremely powerful. Approaches like cap and trade work. ${ }^{107}$ They drive environmental protection AND enhanced profitability. But in the end, markets only allocate scarce resources efficiently in the short term. Adam Smith, the father of markets was very clear that this is all that they were ever intended to do. They were never intended, nor are they any good at protecting grandchildren. This is the job of a free people coming together in a democracy and asking, as Rio+20 did, "What's the future we want?" This is what people created governments to deliver to us, and what we should insist that they attend to.

It might also be useful to revisit how free market economics came to be our dominant story. Adam Smith was not the framer of the heartless version of free markets now popular among austerians. Smith carefully distinguished between economic activity that enables nations to afford military forces to protect their boundaries, and the broader suite of activities that bring happiness to individuals. A moral philosopher, Smith rejected the notion that greed was good, stating in The Theory of Moral Sentiments, the book he was writing when he died, "Hence it is, that to feel much for others, and little for ourselves, that to restrain our selfish, and to indulge our benevolent affections constitutes the perfection of human nature; and can alone produce among mankind that harmony of sentiments and passions in which consists their whole grace and propriety." 108 Smith stated, for example, "The chief part of happiness arises from the consciousness of being beloved... "109

Which returns the concept of gross national happiness. On March 18, 1968, Robert Kennedy put it elegantly, stating:

Too much and for too long, we seemed to have surrendered personal excellence and community values in the mere accumulation of material things... The gross national product counts air pollution and cigarette advertising, and ambulances to clear our highways of

\footnotetext{
${ }^{106} \mathrm{http}: / / \mathrm{www}$.theguardian.com/environment/2015/apr/10/fossilfuel-free-funds-out-performed-conventional-ones-analysis-shows

${ }^{107} \mathrm{http} / / /$ www.sustainablebusiness.com/index.cfm/go/news.display/ id/23763, HTTP://WWW.GRIST.ORG/CLIMATE-POLICY/201111-16-CAP-AND-TRADE-PROGRAM-FUELS-ECONOMIC-GR OWTH-IN-NORTHEAST

${ }^{108}$ Adam Smith, Theory of Moral Sentiments, p 27.

${ }^{109}$ Theory of Moral Sentiments, p 56.
} 
carnage. It counts special locks for our doors and the jails for the people who break them. It counts the destruction of the redwood and the loss of our natural wonder in chaotic sprawl... Yet the gross national product does not allow for the health of our children, the quality of their education or the joy of their play. It does not include the beauty of our poetry or the strength of our marriages, the intelligence of our public debate or the integrity of our public officials. It measures neither our wit nor our courage, neither our wisdom nor our learning, neither our compassion nor our devotion to our country, it measures everything in short, except that which makes life worthwhile. ${ }^{110}$

The economy around us is disintegrating. We know this. People are seeing it in their everyday lives. The recorded music industry is down 64\% from its 1999 peak, ${ }^{111}$ falling from $\$ 38$ billion a year in the late $90 \mathrm{~s}$ to now $\$ 16.5$ billion $^{112}$ and still in profound transformation. But new startup like Spacebar.com are enabling streaming of live music, while delivering more revenues to venues and to musicians. The publishing industry is collapsing under such threats as digital publishing and Amazon. ${ }^{113}$ Into this maelstrom rides the little Douglas County Colorado library system that is offering to publish e-books and give authors $90 \%$ of revenues in its battle with Amazon to enable the library to get affordable e-book licenses. The homemade video Epic2020 ${ }^{114}$ is sending shock waves through traditional academic circles, predicting the collapse of higher education as we know it, yet unaccredited schools such as Singularity University, ${ }^{115}$ entrepreneurial accelerators like Unreasonable Institute ${ }^{116}$ and other niche offerings are flourishing. As big agriculture struggles with fundamental unsustainability, alternatives from the Savory Institute, ${ }^{117}$ winner of the Buckminster Fuller Prize, and movements like slow food, local food and others

\footnotetext{
${ }^{110}$ Kennedy, Robert, remarks at the University of Kansas 18 march 1968, http://www.jfklibrary.org/Historical+Resources/ Archives/Reference+Desk/Speeches/RFK/RFKSpeech68Mar18 UKansas.htm

${ }^{111} \mathrm{http}: / / \mathrm{www} \cdot$ businessinsider.com/these-charts-explain-the-real-de ath-of-the-music-industry-2011-2

112 http://www.forbes.com/sites/forrester/2013/02/27/music-indust ry-stops-losing-money-finally/

${ }^{113} \mathrm{http}: / /$ www.slate.com/blogs/moneybox/2012/01/30/barnes_amp_ noble_and_the_collapse_of_the_publishing_ecosystem.html

${ }^{114}$ http://epic2020.org/

$115 \mathrm{http}: / /$ singularityu.org/

116 http://unreasonableinstitute.org/

${ }^{117}$ http://www.savoryinstitute.com/2013/03/current/ted2013standing-ovation-for-allan-savory/
}

are demonstrating the beginnings of more profitable and more sustainable ways to feed ourselves.

The big transformation, as noted above, of course must come in finance. As Fullerton puts it, "The economy is driving this ecosystem crisis. As a finance person, I know that finance drives the economy. So if the economy is creating the problem, and finance is driving the economy then it sort of leads back to finance."118

Transforming the $\$ 70$ trillion global economy is the real challenge for the Post 2015 Development Goals. Convincing the money managers, the central bankers, the conventional economists that such alternatives as impact investing, slow money movements, complementary currencies and towns that are denying corporate personhood are a more plausible version of the future will take a very powerful story, indeed.

As A.J. Grant points out, marketers know it's much easier to build on something in the brain then to butt in and try to find new room in the cranial real estate for a new idea, Successful marketers, she says-build on something that's in there, something familiar, that the audience is comfortable with-and say that the product is new and improved. Most people crave this sense of the familiar, even staying in abusive relationships because they are familiar.

From this marketer's perspective, the way to manage a transition to a new paradigm is to announce the obvious, to describe what we all know about the industries that are dying, and at the same time, to point out the new industries that are emerging, the telltale signs of the transformation all around us.

Good marketers teach us, she says, to see the changes. The science fiction writer William Gibson said that the future is already here, it's just not widely distributed

We know this. And if it is true that the story precedes change, the real job of the Post 2015 Development goals is to tell the story that stitches together the challenges and the changes.

\footnotetext{
${ }^{118} \mathrm{http}$ ///www.capitalinstitute.org/content/john-interviewed-laura-fl anders-show
} 